\title{
Ryder Glacier in northwest Greenland is shielded from warm Atlantic water by a bathymetric sill
}

Martin Jakobsson (10 1,2凶, Larry A. Mayer ${ }^{3}$, Johan Nilsson ${ }^{2,4}$, Christian Stranne (1) 1,2, Brian Calder ${ }^{3}$, Matthew O'Regan (1) 1,2, John W. Farrell ${ }^{5}$, Thomas M. Cronin ${ }^{6}$, Volker Brüchert1,2, Julek Chawarski(D) ${ }^{7}$, Björn Eriksson 1,2, Jonas Fredriksson (10 1,2, Laura Gemery ${ }^{6}$, Anna Glueder ${ }^{8}$, Felicity A. Holmes ${ }^{2,9}$, Kevin Jerram ${ }^{3}$, Nina Kirchner 2,9, Alan Mix ${ }^{8}$, Julia Muchowski (1) 1,2, Abhay Prakash ${ }^{2,9}$, Brendan Reilly (10 10, Brett Thornton (i) 1,2, Adam Ulfsbo (10) 11, Elizabeth Weidner 1,2,3, Henning Åkesson (10) 1,2, Tamara Handl (10 1,2, Emelie Ståhl 1,2, Lee-Gray Boze ${ }^{12}$, Sam Reed ${ }^{3}$, Gabriel West (1) ${ }^{1,2} \&$ June Padman ${ }^{8}$

The processes controlling advance and retreat of outlet glaciers in fjords draining the Greenland Ice Sheet remain poorly known, undermining assessments of their dynamics and associated sea-level rise in a warming climate. Mass loss of the Greenland Ice Sheet has increased six-fold over the last four decades, with discharge and melt from outlet glaciers comprising key components of this loss. Here we acquired oceanographic data and multibeam bathymetry in the previously uncharted Sherard Osborn Fjord in northwest Greenland where Ryder Glacier drains into the Arctic Ocean. Our data show that warmer subsurface water of Atlantic origin enters the fjord, but Ryder Glacier's floating tongue at its present location is partly protected from the inflow by a bathymetric sill located in the innermost fjord. This reduces under-ice melting of the glacier, providing insight into Ryder Glacier's dynamics and its vulnerability to inflow of Atlantic warmer water.

\footnotetext{
${ }_{1}^{1}$ Department of Geological Sciences, Stockholm University, 10691 Stockholm, Sweden. ${ }^{2}$ Bolin Centre for Climate Research, Stockholm, 10691 Stockholm, Sweden. ${ }^{3}$ Center for Coastal and Ocean Mapping, University of New Hampshire, Durham, NH 03824, USA. ${ }^{4}$ Department of Meteorology, Stockholm University, 10691 Stockholm, Sweden. ${ }^{5}$ United States Arctic Research Commission, Arlington, VA 22203, USA. ${ }^{6}$ Florence Bascom Geoscience Center, U.S. Geological Survey, Reston, VA 21092, USA. ${ }^{7}$ Fisheries and Marine Institute of Memorial University of Newfoundland, St. John's, NL A1C 5R3, Canada. ${ }^{8}$ College of Earth, Ocean, and Atmospheric Sciences, Oregon State University, Corvallis, OR 97331, USA. ${ }^{9}$ Department of Physical Geography, Stockholm University, 10691 Stockholm, Sweden. ${ }^{10}$ Scripps Institution of Oceanography, University of California San Diego, La Jolla, CA 92037, USA.

${ }^{11}$ Department of Marine Sciences, University of Gothenburg, 41319 Gothenburg, Sweden. ${ }^{12}$ U.S. Geological Survey, Woods Hole, MA 02543, USA.

凶email: martin.jakobsson@geo.su.se
} 
T he Greenland Ice Sheet (GrIS) drains into the ocean through marine outlet glaciers with their ice-termini ending either in ice cliffs, where icebergs calve directly from the grounded margin, or in floating ice shelves (ice tongues) ${ }^{1}$, which buttress inland ice and help maintain the stability of the ice sheet $^{2}$. The behaviour of marine outlet glaciers, and rate of icedischarge to the sea, are sensitive to the inflow of subsurface warmer ocean water, as it causes basal melting when in contact with the ice ${ }^{3,4}$. Increased basal melting makes ice tongues thinner and more prone to calving due to general weakening and fracture development ${ }^{5}$. Loss of ice tongues eliminates their potential buttressing effects, in some cases causing grounding-line instability $^{2}$ and increased ice-flow velocity ${ }^{6,7}$. Over the last four decades, the mass loss of the GrIS has increased six-fold ${ }^{8}$. Estimates of the contributions to this mass loss from calving and melting marine outlet glaciers range from $<50 \%{ }^{9}$ to as much as two thirds ${ }^{8}$. In either case, the mass loss from ice dynamics (calving and submarine melt of outlet glaciers) contributes to global sea-level rise ${ }^{8,10}$ and constitutes the largest uncertainty in predictions of future sea level ${ }^{11}$; particularly unresolved is the role of bathymetry and warm-water inflow on ice dynamics ${ }^{12-14}$.

Northwestern Greenland has four fjords that host large marine outlet glaciers that discharge ice into the Arctic Ocean (Fig. 1). Here we present multibeam bathymetry and oceanographic data from the never-before surveyed Sherard Osborn Fjord, one of these fjords. These data, collected from the Swedish icebreaker Oden in 2019, mapped almost all of Sherard Osborn Fjord where Ryder Glacier drains into the Lincoln Sea in the Arctic Ocean (Fig. 1). Together with Petermann Glacier, which drains into Nares Strait, Ryder Glacier is the only other marine outlet glacier in northwestern Greenland that still has a large (>10 km long) floating ice tongue ${ }^{15,16}$. Petermann Fjord and the adjacent part of the Nares Strait were mapped with multibeam by Oden in $2015^{17}$, and in 2019 we acquired new oceanographic data from Petermann Fjord, allowing a comparison of these two fjords with ice tongues.

During the most recent decades Petermann and Ryder glaciers have behaved somewhat differently. While Petermann lost nearly

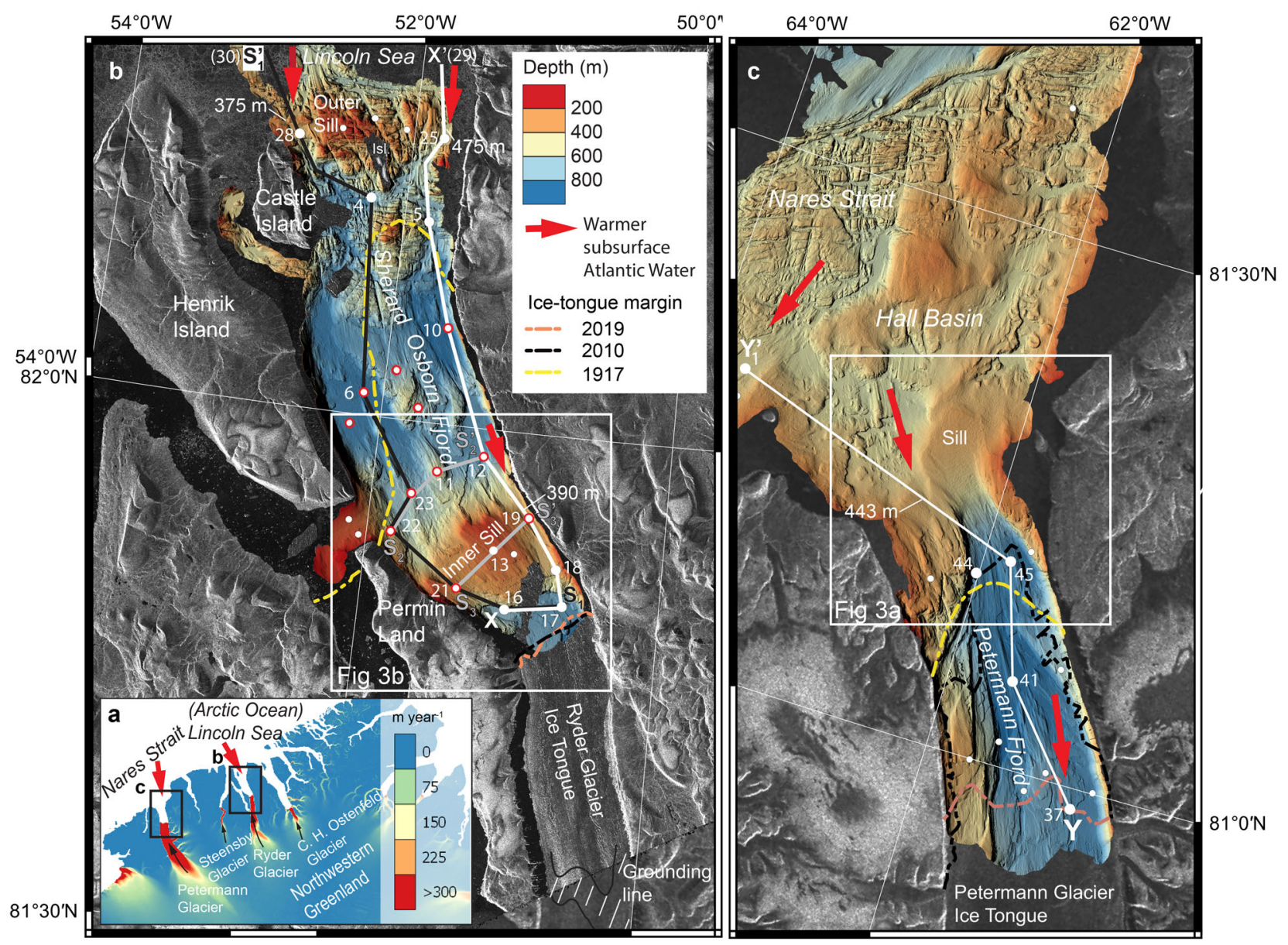

Fig. 1 Locations of Sherard Osborn and Petermann fjords where, respectively, Ryder Glacier and Petermann Glacier drain the North sector of the GrIS. a Ice velocity, in $m$ per year, of the marine outlet glaciers from the MEaSUREs project ${ }^{44}$. $\mathbf{b}$ Newly collected multibeam bathymetry of the Sherard Osborn Fjord reveals the inner and outer bathymetric sills separated by a basin with a maximum water depth of $890 \mathrm{~m}$. The deepest passages over the sills are marked along with their depths. c Multibeam bathymetry collected in Petermann Fjord in $2015^{17}$ shows a pronounced sill located at the mouth of the fjord. The deepest threshold of this sill is $443 \mathrm{~m}$ and the maximum depth of Petermann Fjord is $1158 \mathrm{~m}$. The white dots in $\mathbf{a}$ and $\mathbf{b}$ are the conductivity, temperature and depth (CTD) stations shown in Fig. 3. The white dots with a red border are averaged and used in the plume modelling. Stations connected with a white line and marked with station numbers are used to construct the water temperature profiles $X-X^{\prime}$ and $Y^{\prime} Y^{\prime}$ in Fig. 3. Three additional profiles, $\mathrm{S}_{1}-\mathrm{S}_{1}{ }^{\prime}, \mathrm{S}_{2}-\mathrm{S}_{2}{ }^{\prime}$ and $\mathrm{S}_{3}-\mathrm{S}_{3}{ }^{\prime}$, along the paths of the black (along fjord) and grey (across fjord) lines are shown in the Supplementary Fig. 2. Station 44 in Petermann Fjord is marked with its number because it is shown in Fig. 5. The background image is from Radarsat where ice and land show up in different shades of grey while open water is black. The 1917 ice-tongue extents are digitized from historical maps by Danish geologist Lauge Koch ${ }^{23}$, while 2010 and 2019 are inferred from satellite images. 
$40 \%$ of its floating ice tongue in major calving events in 2010 and $2012^{18,19}$, and has undergone an average net retreat of $311 \mathrm{~m} \mathrm{a}^{-1}$ between 1948 and 2015, Ryder experienced a small average icetongue advance of $43 \mathrm{~m} \mathrm{a}^{-1}$ during the same period ${ }^{15}$. It should be noted that Ryder Glacier also behaved differently in that it showed cycles of advance ( $\sim 7$ years) and retreat ( $\sim 2$ years) over this time period, a behaviour which has been suggested to be controlled by the basal topography at the grounding line ${ }^{15}$.

Our bathymetric and oceanographic data from Sherard Osborn Fjord allow a direct comparison with those from Petermann Fjord, thus permitting an assessment of Ryder and Petermann glaciers' exposure and vulnerability to inflow of warmer subsurface water. While the two glaciers have behaved differently in recent decades we note that from a longer time perspective the ice tongue of Ryder Glacier has a more withdrawn position with respect to the fjord mouth than Petermann Glacier. Our measurements demonstrate that the intermediate-depth water mass of relatively warm and salty water, referred to as Atlantic Water that enters the central Arctic Ocean through the Fram Strait and the Barents $\mathrm{Sea}^{20}$, is present in both fjords. In Petermann Fjord, this water mass enters over a single bathymetric sill located at the mouth of the fjord and accelerates melting of the Petermann Glacier $^{21}$. Sherard Osborn Fjord, however, has two sills. Here we examine if this bathymetric difference has an effect on the impact of Atlantic Water on the basal melt rate of Ryder Glacier and, thus, whether the bathymetry could be a factor contributing to the different behaviours of these two glaciers over the recent decades. Our study emphasizes the critical role of fjord circulation and bathymetry in the assessments of the future fate of outlet glaciers and sea-level rise in a warming climate.

\section{Results}

During the 37-day Ryder 2019 Expedition (August 5-September 10, 2019) with Swedish icebreaker Oden, 15 days were dedicated to Sherard Osborn Fjord and the area directly north of the fjord entrance (Fig. 1). The expedition also carried out research in areas of Nares Strait and Lincoln Sea between Petermann Fjord and Sherard Osborn Fjord as well as within Petermann Fjord.

Fjord dimensions and seafloor bathymetry. Sherard Osborn Fjord is $\sim 17 \mathrm{~km}$ wide and $\sim 55 \mathrm{~km}$ long, measured from the present ice-tongue margin of Ryder Glacier to the outer sill (described below), while Petermann Fjord's equivalent dimensions are $\sim 17$ and $40 \mathrm{~km}$, respectively (Fig. 1). Available moderate resolution imaging spectroradiometer (MODIS) satellite images dating back to 2001 reveal that large icebergs, calved from the ice tongue of Ryder Glacier, remain trapped inside the fjord because the prevailing sea ice at the mouth prevents their exit. In contrast, icebergs calved from Petermann Glacier are rapidly flushed out of the fjord. Several of the icebergs currently in Sherard Osborn Fjord may be relics from calving events prior to the $1950 \mathrm{~s}^{22}$. In 1917 Danish geologist Lauge Koch observed that nearly the entire fjord up until the level of southern Castle Island was covered by Ryder Glacier's ice tongue ${ }^{23}$, indicating that, like Petermann Glacier, Ryder Glacier has also had a long-term retreat (Fig. 1). During our expedition, icebergs that had calved from the ice tongue, reaching sizes of about $9 \times 4 \mathrm{~km}$, moved constantly within the fjord and hindered access to the few areas that were left unmapped. The ice tongue of Petermann Glacier was located only about $5 \mathrm{~km}$ inside the sill at the fjord mouth before the major calving event in $2010^{18}$, a position that was close to observations of the Petermann ice-tongue margin made by Lauge Koch in 1917 and 1921-1922 23 (Fig. 1). Thus, the ice tongues of Ryder and Petermann glaciers had similar positions with respect to the outer sills in their hosting fjords in 1917.
The multibeam sonar data from Sherard Osborn Fjord reveal bathymetry dominated by bedrock structures and submarine glacial landforms that most likely date back to the last deglaciation (Fig. 1a; Supplementary Fig. 1). Two prominent bathymetric sills extend across the entire width of the fjord at their respective locations. The outer sill is located at the fjord mouth in line with Castle Island while the inner sill's northern extent does not fully reach Permin Land's northern point (Fig. 1a). The morphology of the outer sill, at the fjord mouth, suggests that it is mainly comprised of bedrock. It has a central region roughly $8 \mathrm{~km}$ wide, with depths shallower than $350 \mathrm{~m}$, and two islands forming part of this section of the sill. Deeper channels into the fjord are found on either side of this central bathymetric high, setting the outer fjord's sill depth to $475 \mathrm{~m}$ on the eastern side and $375 \mathrm{~m}$ on the western side (Fig. 1).

The seafloor of the inner sill is smoother than the outer sill, likely due to the fact that its surface morphology is less dominated by bedrock structures than the outer sill. We interpret the inner sill to be a sedimented glacial grounding zone ${ }^{24}$ formed when Ryder Glacier's grounded margin was further seaward and positioned at this location. It has a classic asymmetric geometry with retrograde slope on the ice-proximal side ${ }^{25,26}$, supporting our interpretation of the sill's origin as a glacial grounding zone, and a $\sim 6.2 \mathrm{~km}$ wide central region that is shallower than $300 \mathrm{~m}$ (shallowest point is $193 \mathrm{~m}$ ). The sill depth is $390 \mathrm{~m}$ and is located in a $\sim 1 \mathrm{~km}$ wide channel on the eastern side. The present icetongue terminus of Ryder Glacier is located $\sim 5 \mathrm{~km}$ landward of the inner sill. The multibeam sonar swath reached about $1 \mathrm{~km}$ underneath the ice tongue. There, we observed several steep bathymetric steps (dropping down more than $100 \mathrm{~m}$ with slopes up to $50^{\circ}$ ) in the seafloor, interpreted to be bedrock-controlled.

The seafloor morphology of Petermann Fjord, including bathymetric characteristics of the sill, has been described previously ${ }^{17}$. The description was based on multibeam bathymetry acquired in 2015 using icebreaker Oden and the same multibeam system as used this study. In summary, the bathymetric mapping revealed one major sill located at the fjord mouth, where it extends across the width of the fjord and has a maximum depth of $443 \mathrm{~m}$ (Fig. 1c, Supplementary Fig. 1). The sill is generally shallower than $400 \mathrm{~m}$ and separates the overdeepened fjord, reaching $1158 \mathrm{~m}$, from the $\sim 200-600 \mathrm{~m}$ deep Hall Basin of Nares Strait. The sills of Petermann and Sherard Osborn fjords are further compared below.

Temperature and salinity distribution. Oceanographic stations including conductivity, temperature, depth (CTD) profiles were acquired at 25 locations within Sherard Osborn Fjord and at three locations outside the fjord mouth in the nearby area of the Lincoln Sea (Fig. 1b). In addition, 21 CTD stations were acquired in Nares Strait and Petermann Fjord (Fig. 1c).

An upper cold and relatively fresh water layer is present in all CTD profiles from Sherard Osborn Fjord and the nearby area of the Lincoln Sea (Fig. 2). The core of this layer is situated at a depth around $50 \mathrm{~m}$ and has a temperature of about $-1.5^{\circ} \mathrm{C}$ and salinity below 32. Below this upper layer, the water temperature and salinity gradually increase with depth. The profiles from Sherard Osborn Fjord reveal a clear temperature difference between the waters landward of the inner sill and seaward of this sill in the main fjord basin, at depths greater than about $250 \mathrm{~m}$ (Fig. 2, see Fig. 1 for CTD locations). Seaward of the outer sill in Sherard Osborn Fjord, in the Lincoln Sea, the waters from about $\geq 150 \mathrm{~m}$ are warmer than at equivalent depths within the fjord. A temperature transect through a subset of these stations shows these temperature contrasts between waters on the inland side of and below the inner sill, and those in the main fjord and Lincoln 



\begin{abstract}
Fig. 2 Potential temperature and salinity from conductivity, temperature and depth (CTD) stations in Sherard Osborn and Petermann fjords as well as from the Lincoln Sea and Nares Strait, just outside respective fjords. a, b Potential temperature and salinity in the outer Sherard Osborn Fjord (red) and behind the inner sill (black), referred to as the inner fjord. Profiles from the Lincoln Sea located outside the outer sill of Sherard Osborn Fjord are shown in blue. c, $\mathbf{d}$ Potential temperature and salinity in Petermann Fjord (red) and Nares Strait (blue). The near-surface temperature minimum, at around $50 \mathrm{~m}$ in the fjords, represents water formed by seasonal sea-ice growth. Water of Atlantic origin is seen in both fjords from about $350 \mathrm{~m}$ water depth where temperatures are $>0.3^{\circ} \mathrm{C}$ and salinities are $>34.7$. The temperature does not exceed $0.2^{\circ} \mathrm{C}$ inside the inner sill in Sherard Osborn Fjord $\mathbf{a}$ and the salinity is also lower $\mathbf{b}$
\end{abstract}

Sea (Fig. 3). The $>0.3{ }^{\circ} \mathrm{C}$ warm water with salinity above 34.7 in the main fjord, from about $350 \mathrm{~m}$ to the bottom, must be of Atlantic origin as no other source brings heat into the Arctic in this salinity range ${ }^{27}$. Inland of the inner sill, in contrast, the temperature is around $0{ }^{\circ} \mathrm{C}$, never reaching $0.2^{\circ} \mathrm{C}$ (Figs. 2 and 3), and has a temperature-salinity relationship that shows more influence from glacial meltwater than in the main fjord basin (Fig. 4). Three additional temperature profiles constructed through CTD stations are shown in the Supplementary Fig. 2; one along the fjord parallel to profile $\mathrm{X}-\mathrm{X}^{\prime}$ in Fig. $3 \mathrm{a}$ and two across the fjord, from west to east, one just north (seaward) of the inner sill and the other along the top of the inner sill. These profiles show that the temperature stratification across Sherard Osborn Fjord is rather homogenous, with small variations likely attributed to eddies and internal waves from wind forcing and tides. The temperature contrast between the waters inland relative to those seaward of the inner sill is clearly seen in profile $\mathrm{S} 1-\mathrm{S1}^{\prime}$ parallel to $\mathrm{X}-\mathrm{X}^{\prime}$ (Fig. 3 and Supplementary Fig 2a). The warmwater blockage effect from the shallower parts of the inner sill is visible in profile $S_{3}-S_{3}$ (Supplementary Fig. 2c).

The temperature and salinity distributions in Petermann Fjord is generally similar to the outer Sherard Osborn Fjord, although there is a difference in that the upper core of colder water at about $50 \mathrm{~m}$ depth is slightly colder in Sherard Osborn Fjord (Figs. 2 and 3 ). It should also be noted that the Atlantic Water was slightly warmer in Lincoln Sea outside of Sherard Osborn Fjord than in Nares Strait outside of Petermann Fjord (Fig. 3).
Comparing Petermann and Sherard Osborn fjords. We compare the inner sill in Sherard Osborn Fjord with the sill at the mouth of Petermann Fjord mapped in $2015^{17}$, as these two sills comprise the documented bathymetric blockages for inflowing subsurface Atlantic Water closest to the respective glaciers. The cross-sectional area calculated for each sill between the sill's shallowest points, projected onto the shortest distances across the sill (Fig. 5a, b), provides a comparative measure of the gateway's size for inflowing subsurface warmer water towards the respective glacier. This provides a metric of the connectivity between the basin inside of the sill and warm subsurface Atlantic Water seaward of the sill. We further constrain this cross-sectional area to include mainly the relatively warm subsurface waters that flows toward the glaciers in Petermann and Sherard Osborn fjords. As shown in Fig. 4, the subsurface waters colder than around $0{ }^{\circ} \mathrm{C}$ have generally been modified by interactions with the ice tongues and are therefore likely to flow seaward. Thus, we limit the crosssectional area to only include the subsurface water warmer than $0{ }^{\circ} \mathrm{C}$, which encompasses the water of Atlantic origin ${ }^{27}$ with high basal-melt potential relative to the local freezing point, which is near $-2{ }^{\circ} \mathrm{C}$. Supplementary Fig. 3 illustrates how these areas have been calculated. The area calculated for the inner sill in Sherard Osborn Fjord is $\sim 264 \times 10^{3} \mathrm{~m}^{2}$, from where the depth level is $0{ }^{\circ} \mathrm{C}$ $(275 \mathrm{~m})$, while it is $\sim 1991 \times 10^{3} \mathrm{~m}^{2}$ in Petermann Fjord from where the depth level is $0{ }^{\circ} \mathrm{C}(221 \mathrm{~m})$ (Fig. 5c). Thus, the crosssectional area through which water $\geq 0{ }^{\circ} \mathrm{C}$ can transit the sill is as much as $\sim 7.5$ times larger in Petermann Fjord. If we instead 


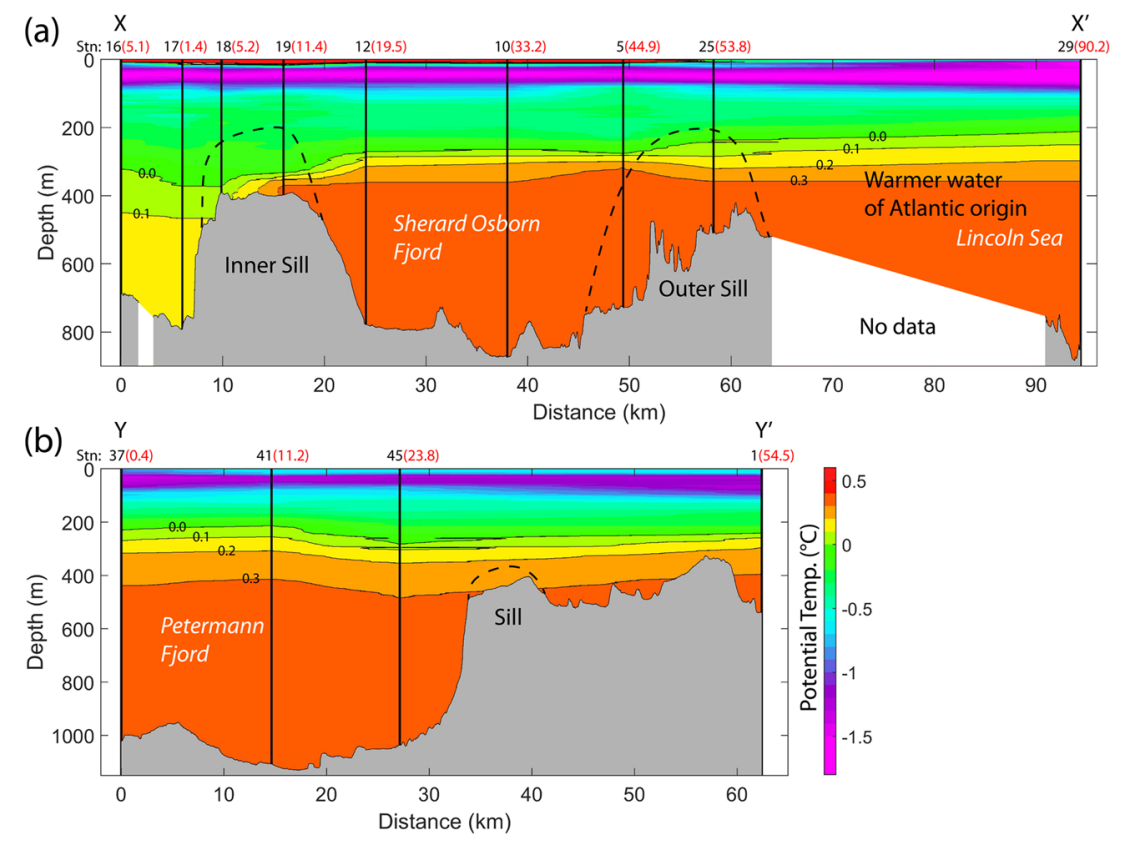

Fig. 3 Temperature profiles along Sherard Osborn and Petermann fjords. The temperature profiles, from $X$ to $X^{\prime}$ (a; Sherard Osborn Fjord) and $Y$ to $Y^{\prime}$ (b; Petermann Fjord) are based on conductivity, temperature and depth (CTD) stations shown in Fig. 1 and numbered at the top of the profiles. Numbers within brackets in red next to the station numbers are the closest distances in kilometres to the 2019 location of the ice tongue margins in respective fjords. The depth profiles are derived from the multibeam bathymetry. Note that the profiles run through the deepest passages across the sills. The sill-crests are indicated by black dashed lines, and are substantially shallower in Sherard Osborn Fjord. Additional temperature profiles constructed from CTD stations in Sherard Osborn Fjord are shown in the Supplementary Fig. 2.

compare the cross-sectional areas above the sills for the same depth reference level in both fjords, here assigned to $248 \mathrm{~m}$ (the midpoint between 275 and $221 \mathrm{~m}$ ), the water passage area is 3.4 times larger in Petermann Fjord.

A comparison between the temperature profiles in Sherard Osborn Fjord from landward and seaward of the inner sill and a corresponding profile landward of Petermann's bathymetric sill at the fjord mouth seems to confirm that Petermann Glacier does not benefit from the sill protection that Ryder Glacier does; Petermann Glacier is consequently exposed to significantly warmer subsurface waters (Fig. 5). The role of the sill geometries for ice-ocean interactions is further supported by remote-sensing estimates of the two ice tongues' basal melting, which suggest that the submarine melt flux (measured in $\mathrm{km}^{3} \mathrm{yr}^{-1}$ ), driven by ocean heat flux, is roughly five times larger for Petermann than for Ryder $^{28}$. However, if we account for the difference in ice-tongue sizes by converting these data to melt per unit area, the difference is diminished but remains: the basal melt rate per unit area is about 20\% larger for Petermann than for Ryder. Following a comparison between the volumes underneath the two ice tongues, we present numerical modelling that suggests that the lower near ice-tongue ocean temperatures in the Sherard Osborne Fjord can explain a melt-rate decrease per unit area of this observationally inferred magnitude.

The volume of the $\geq 0{ }^{\circ} \mathrm{C}$ waters, occupying the area between the grounding lines and the constraining sills in the two fjords, are substantially different. In Petermann Fjord, this $\geq 0{ }^{\circ} \mathrm{C}$ water occurs from a depth of $\sim 225 \mathrm{~m}$ inside the sill at the fjord mouth and amounts to a volume of $980 \mathrm{~km}^{3}$. The equivalent water mass is found at $\sim 275 \mathrm{~m}$ in Sherard Osborn Fjord and reaches a volume of $\sim 180 \mathrm{~km}^{3}$ between the inner sill and Ryder Glacier's grounding line, i.e. a volume smaller than one-fifth of that found in Petermann Fjord. These volumes are rough estimates. Since we do not have temperature profiles from below the ice tongues, we have simply extended the water masses occupying depths below $0{ }^{\circ} \mathrm{C}$ temperature back to the grounding lines in both fjords and subtracted the volume occupied by ice from depths deeper than $275 \mathrm{~m}$ in Sherard Osborn Fjord and $225 \mathrm{~m}$ in Petermann Fjord.

The impact of the colder subsurface waters inside the inner sill in Sherard Osborn Fjord on subglacial melt rates is examined by applying a one-dimensional buoyant-plume model, based on conservation of mass, momentum, heat, and salt ${ }^{29,30}$. We performed model runs with two different boundary conditions; one with ambient salinity and temperature profiles from inside the inner sill close to the ice-tongue terminus (CTD station 17, Fig. 1b) and the other with CTD profiles from seaward of the inner sill, in the main basin (average over CTD stations marked in Fig. 1b). The model setup and results are presented in the Supplementary information. The modelling results show that the average subglacial melt rate on Ryder Glacier tongue is about $15 \%$ higher when using boundary conditions from the warmer main basin of the fjord compared to the colder boundary conditions close to the terminus provided by the temperature profile from CTD station 17.

In summary, Petermann Glacier, with a bathymetric sill located more than $40 \mathrm{~km}$ from the current ice-tongue terminus and a maximum depth of $443 \mathrm{~m}$, is far more exposed to inflow of warmer Atlantic Water than Ryder Glacier, which is protected by an inner sill in Sherard Osborn Fjord with a maximum depth of $390 \mathrm{~m}$ restricted to a narrow, $1 \mathrm{~km}$ wide channel (Figs. 1 and 5).

\section{Discussion}

The impact of inflowing warm water on marine terminating glaciers with ice tongues was observed in western Greenland when, in 1997, the Jakobshavn Glacier thinned rapidly due to a sudden increase in subsurface temperature, attributed to inflow of water from the Irminger Sea near Iceland ${ }^{31}$. When Jakobshavn lost 

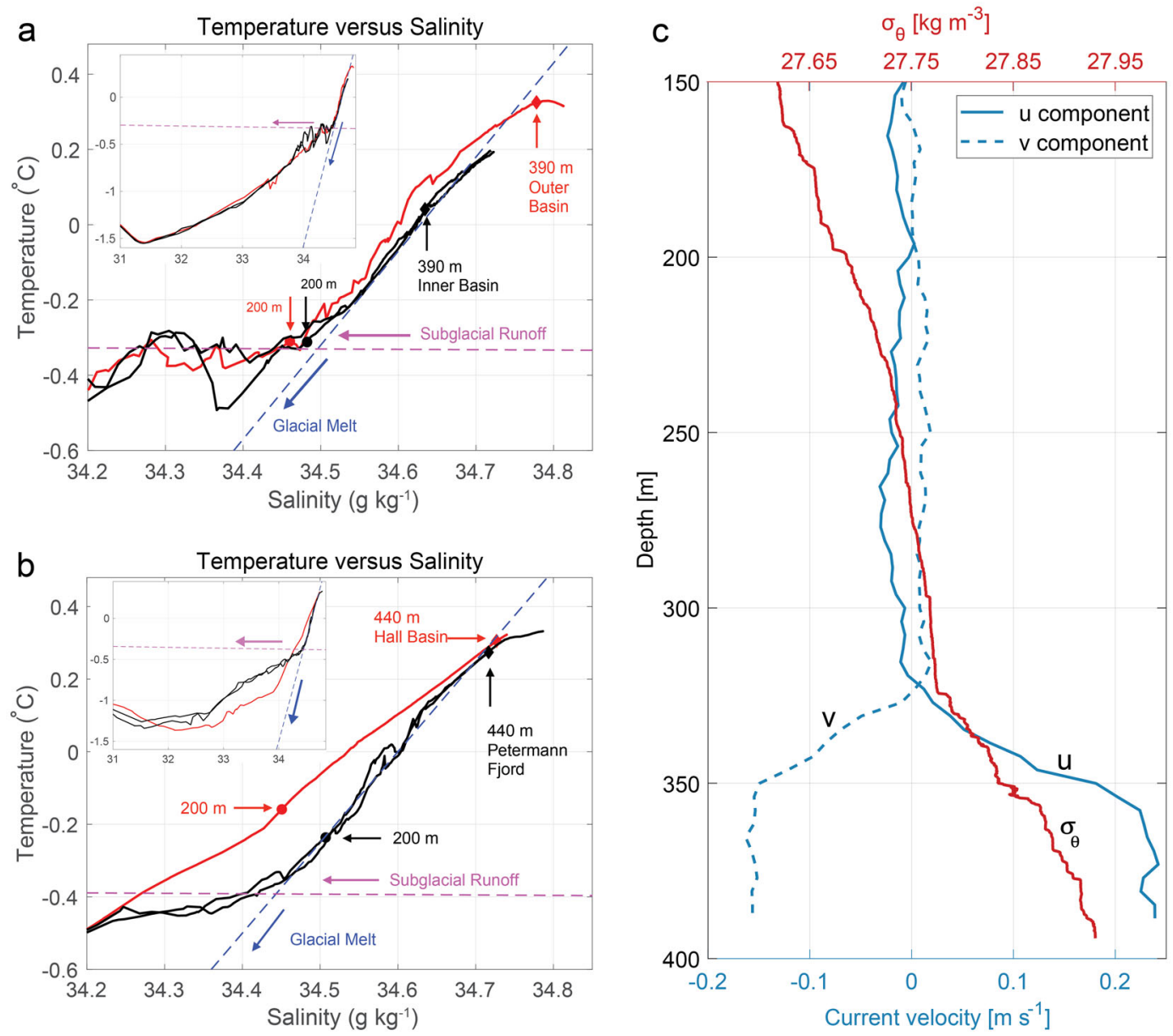

Fig. 4 Temperature-salinity relation for the conductivity, temperature, and depth (CTD) stations and current velocity from ADCP profile.

a CTD-profiles from landward of the inner sill $(\# 16,17$, black) and directly north of it (\#12, red) in Sherard Osborn Fjord. b CTD-profiles from inside (\#37,45, black) and outside (\#1, red) of the sill in Petermann Fjord (see Fig. 1 for locations of stations). The small insets in $\mathbf{a}$ and $\mathbf{b}$ show the full salinity and temperature ranges to provide overviews. The dashed blue line shows the temperature-salinity relation resulting when ocean water melts ice ${ }^{35}$ and the dashed magenta line shows the relation resulting from mixing between ocean water and freshwater injected by subglacial discharge ${ }^{36}$. Note that the waters in Sherard Osborn Fjord landward of the inner sill (Inner Basin) are colder and fresher than the waters in the outer fjord (Outer Basin) from the top of the inner sill at about $200 \mathrm{~m}$ all the way to the bottom, indicating an influence on the physical oceanography of Ryder Glacier on the inner fjord basin. $\mathbf{c}$ Current velocity from ADCP data and density profile at station \#19 located in the relatively narrow channel forming the deepest passage across the inner sill in Sherard Osborn Fjord. The $u$ and $v$ component show the east and north velocities, respectively, capturing a situation with a near bottom inflow towards the southeast in the channel.

nearly all of its tongue in the early 2000s, iceberg calving directly from the ice-cliff margin increased drastically ${ }^{32}$. Jakobshavn drains into the Ilulissat Icefjord, which has a sill of 200-245 m depth at the fjord mouth that apparently is too deep at that location to shield the basal ice-tongue melt from responding strongly to subsurface Atlantic Water temperature changes in the Irminger Sea outside the fjord ${ }^{31}$. This lack of an effective barrier to inflow of warm subsurface waters is similar to the setting at Petermann Fjord but contrasts with the apparent restriction of warm subsurface water penetration across the shallow inner sill observed in Sherard Osborn Fjord. The hydrographic and bathymetric setting in Sherard Osborn Fjord is to some extent similar to that of the 79 North Glacier in Northeast Greenland where a pronounced sill crossed by a narrow channel constricts the inflow of warm subsurface Atlantic Water ${ }^{14}$.

Based on the subglacial bed topography map of Greenland BedMachine $\mathrm{v}^{33}$, the present grounding line of Ryder Glacier is located $\sim 26 \mathrm{~km}$ south of the ice-tongue terminus at the time of our expedition (August 2019) and is found at a mean water depth of about $550 \mathrm{~m}$. Ocean temperatures inland of the inner sill at the grounding-line depth and along the ice tongue are significantly colder than typical Atlantic Water temperatures seen in the Lincoln Sea and Nares Strait ${ }^{21}$ (Figs. 2 and 3). This appears to be in stark contrast with the Petermann Glacier where a deeper, wider and smoother sill located $\sim 40 \mathrm{~km}$ from the present ice tongue terminus allows significant interaction between inflowing Atlantic Water and the glacier ${ }^{21}$. Previously reported bathymetric data from Petermann Fjord, derived through gravity inversion, indicate the possible presence of a sill with depths of 540-640 m underneath Petermann ice tongue, $\sim 25 \mathrm{~km}$ north of the grounding line ${ }^{34}$. Three holes were drilled through the Petermann ice tongue in 2015 , one of which was located about $16 \mathrm{~km}$ seaward of the grounding line ${ }^{21}$, landward of the potential sill. Water temperatures below this hole were about $0.3^{\circ} \mathrm{C}$ at $450 \mathrm{~m}$ water depth ${ }^{21}$, indicating that if a bathymetric sill exists underneath the Petermann ice tongue, it does not have the same restricting effect on the inflowing warmer subsurface water as the inner sill has in Sherard Osborn Fjord. 


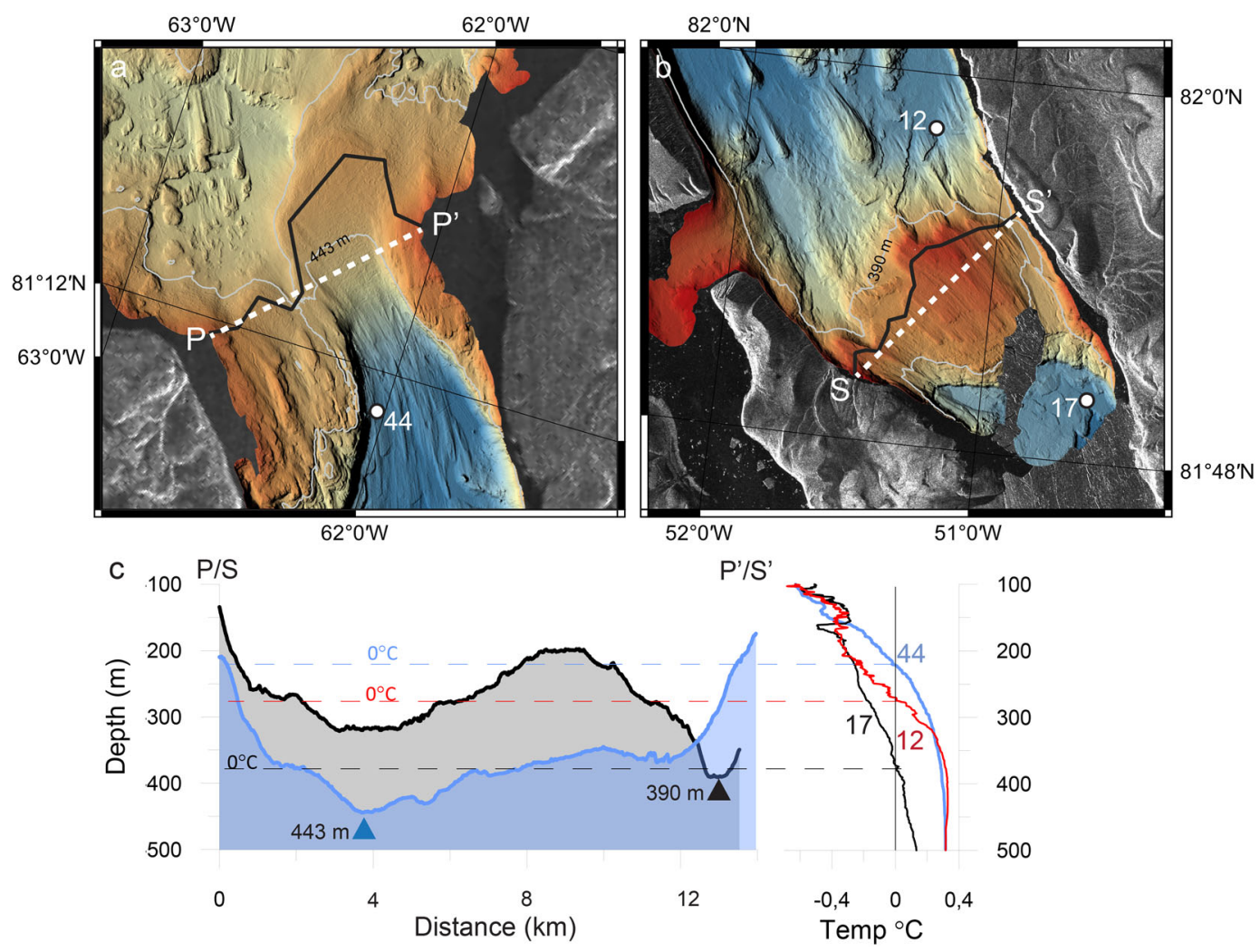

Fig. 5 Comparison of bathymetric sills in the Petermann and Sherard Osborn fjords. The bathymetry is shown for the outer sill in Petermann Fjord a and the inner sill in Sherard Osborn Fjord $\mathbf{b}$. The shallowest passages across the sills are marked by black lines. The depths along these black lines are projected onto the profiles $\mathrm{P}-\mathrm{P}^{\prime}$ and $\mathrm{S}-\mathrm{S}^{\prime}$ (blue and black profiles in b, respectively) in order to compare the two sills with respect to how water flows across them. Temperature profiles from conductivity, temperature, and depth (CTD) stations (c; locations shown in $\mathbf{a}$ and $\mathbf{b}$ ) reveal clear temperature differences inland of the sills in the two fjords, with colder water from deeper than $\sim 200 \mathrm{~m}$ in Sherard Osborn Fjord.

We propose that the bathymetric differences between Petermann and Sherard Osborn fjords have played a role in the different responses of the two glaciers to oceanic forcing over the past decades. The plume-model results indicate that the colder water temperatures near the grounding-line on Ryder Glacier potentially could result in $15 \%$ lower basal melt rates than if the warmer water outside of the inner sill would be permitted to flow unconstrained towards the glacier. However, the estimated melt rates from the plume-model must be considered a rough firstorder approximation. More important is the fact that we observe colder water temperatures landward of the inner sill in Sherard Osborn Fjord than seaward.

The question of what maintains the water temperatures to be relatively lower at comparable depths inland of and below the inner sill in Sherard Osborn Fjord compared to seaward remains to be addressed. Interactions with the ice tongue must be the primary reason. This is evident from the temperature-salinity relationship inland of the inner sill between 200 and $500 \mathrm{~m}$ (Fig. 4) showing cooling and freshening from glacial melt in the lower part of this depth interval following the typical relationship shown by $\mathrm{H}$. Gade ${ }^{35}$, and the influence of subglacial discharge in its upper part ${ }^{36}$. To explain the lower temperatures inland of the inner sill we suggest that when the warmer water from the outer Sherard Osborn Fjord flows inwards over the inner sill, through the $<1 \mathrm{~km}$ wide channel formed in its eastern side, it mixes with the overlying colder and glacially modified outflowing waters. The concept is illustrated in Fig. 6. That vertical mixing occurs is supported by acoustic Doppler current profiler (ADCP) velocity and CTD measurements taken at station 19, located in the narrow deepest passage on the eastern inner sill (Figs. 1 and 4c). Here, the warm $\left(\sim 0.3^{\circ} \mathrm{C}\right)$ inflowing water occupies only a $50 \mathrm{~m}$-thick bottom layer that flows towards the ice tongue with speeds reaching $>0.2 \mathrm{~m} \mathrm{~s}^{-1}$. An indication of the strength of shear-driven vertical mixing can be obtained from the Richardson number given by

$$
\mathrm{Ri}=\frac{g^{\prime} h}{U^{2}},
$$

where $U$ is the velocity in the bottom layer, $h$ its height and $g^{\prime}$ the reduced gravity. Vertical mixing is expected if $\mathrm{Ri}<0.8^{37}$ and from Fig. $4 \mathrm{c}$, taking $h=50 \mathrm{~m}, U=0.2 \mathrm{~m} \mathrm{~s}^{-1}$ and $g^{\prime}=5 \times 10^{-4} \mathrm{~m} \mathrm{~s}^{-2}$ we find that $\mathrm{Ri} \approx 0.6$. Presumably, the velocity and mixing increase when the near-bottom inflow descends along the steepening sill into the ice cavity. The sill in Petermann Fjord, on the other hand, is wider and has a more uniform depth in the crossfjord direction (Fig. 5). Here, the mean inflow is presumably in geostrophic balance, more broadly distributed and associated with weaker vertical mixing ${ }^{38}$. In Sherard Osborn Fjord, the confinement of the warm-water inflow to a narrow deep passage over the inner sill with steep $\left(>50^{\circ}\right)$ vertical steps on the inner slope, serves to enhance vertical mixing, thereby cooling the water reaching the Ryder Glacier's grounding line, where glaciers are most vulnerable. If the speed and volume of inflowing water increases toward Ryder Glacier, mixing and cooling should increase. Thus, the depth and structure of the inner sill in Sherard Osborne Fjord is likely to decrease the sensitivity of the ice tongue to changes of the properties of the warmer Atlantic Water residing in the outer fjord.

It is primarily inside the inner sill in the Sherard Osborn Fjord that the oceanographic conditions differ significantly from those in Petermann Fjord (Fig. 3). It is plausible that the near co- 


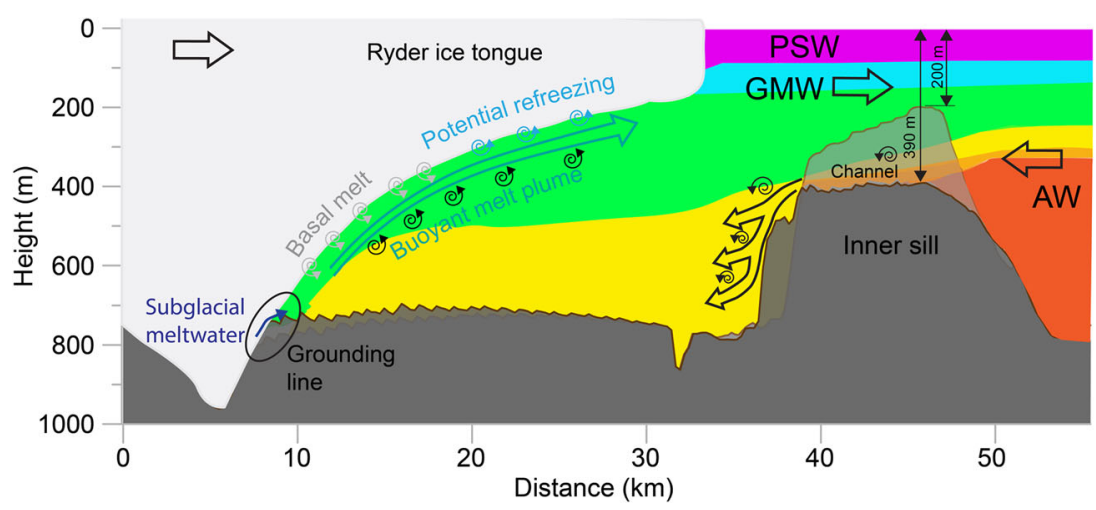

Fig. 6 Schematic illustration showing how Atlantic Water (AW) is interpreted to flow through the $<1 \mathrm{~km}$ wide and $390 \mathrm{~m}$ deep channel across the inner sill to be mixed and cooled by glacially modified water (GMW). Lighter polar surface water (PSW) floats above the GMW layer. With a shallowest point of about 200 m, the main part of the inner sill in front of Ryder Glacier is too shallow for the warmer core of AW to flow across. Inland of the inner sill, and beyond the extent of our multibeam mapping, the bathymetric profile shown has been extracted from BedMachine v $3^{33}$. The extent of Ryder Glacier's ice tongue is inferred from satellite images from August 2019.

location of the ice tongue and the inner sill in the Sherard Osborn Fjord in addition to the double-sill configuration are important for the ice-ocean interactions at Ryder Glacier. This can potentially further constrict the exchange over the inner sill that is only about $3-5 \mathrm{~km}$ away from the ice-tongue terminus. Additional studies are warranted to examine how the distance between the ice-tongue terminus and a sill can affect ice-ocean interactions and residence times in ice cavities ${ }^{39,40}$.

Our study advances our overall quest to improve projections of ice-sheet mass loss via fjord-bound outlet glaciers and associated sea-level rise. In particular, we find that basal melting at the grounding line in fjord settings can be critically influenced by the sill geometry. The results from Sherard Osborn Fjord presented here are based on a 2-week field campaign during late summer in 2019. Thus, we cannot be assured that the observed absence of warmer Atlantic Waters near the Ryder Glacier ice tongue represents oceanographic conditions in the fjord over a longer time period. Furthermore, the more northerly location of Ryder Glacier compared to Petermann Glacier is another component that may influence the dynamics of the two glaciers, in particular if this implies different access to warmer Atlantic Water outside of the hosting fjords. While our oceanographic stations show slightly warmer subsurface water outside of Sherard Osborn Fjord in Lincoln Sea than in Nares Strait (Fig. 2), we cannot discern from our limited data if this represents a long-term regional pattern or an anomaly for 2019.

However, the stability of the Ryder Glacier ice tongue over the last decades seems to suggest that variations in water temperatures at its grounding line and associated melting rates have been modest. We also note that our CTD stations and geophysical mapping do not directly provide the conditions at the grounding line about $26 \mathrm{~km}$ from the ice-tongue margin. Oceanographic moorings with temperature loggers placed in Sherard Osborn Fjord at strategic locations are needed to resolve this question. Finally, we have not addressed potential influences of fjord geometry and side-wall stresses on glacial flow in this study, which may be critical for the advance- and retreat-dynamics of Ryder and Petermann glaciers. In particular, the narrowing of Sherard Osborn Fjord that occurs from the inner sill to where the ice tongue of Ryder Glacier presently is located may have played a stabilizing role and prevented further retreat.

\section{Methods}

Multibeam bathymetry. Bathymetric mapping was conducted during the Ryder 2019 Expedition in Sherard Osborn Fjord between 2019-08-11 and 2019-08-25 using the Kongsberg EM122 $\left(12 \mathrm{kHz}, 1^{\circ} \times 1^{\circ}\right)$ multibeam echosounder installed on icebreaker Oden. The multibeam is supported by a Kongsberg Seapath 320 navigation system including a MRU5 motion sensor. Profiles of sound speed as a function of depth derived from the coincident physical oceanography programme (see below) were used to correct for acoustic refraction in the bathymetric data, and a near-sonar sound speed sensor was used for real-time beamforming. Data were resolved to instantaneous sea level. A calibration, known as a patch test, was conducted for Oden on 2019-08-21 in Sherard Osborn Fjord and calibration results were applied to all bathymetric data.

All bathymetric data were processed using QPS Qimera software, version 1.7.6. During processing data were associated with their nearest in-time (as opposed to previous), sound speed profile, re-corrected for refraction effects using an automatically determined empirical correction where required, and then re-computed for depth. A total propagated uncertainty was computed for each sounding using sonar-specific parameters, and the combined uncertainty and bathymetric estimator (CUBE) algorithm ${ }^{41}$ implementation within Qimera was used to generate depth estimates in a series of $15 \mathrm{~m}$ grids. A North Polar Stereographic projection with true scale at $75^{\circ} \mathrm{N}$ and zero meridian through Greenwich was used for grid construction. The depth estimates were inspected immediately post-collection by the expedition party for anomalies (e.g., due to the noise induced by breaking ice, poorly corrected refraction, acoustic sideechoes, or in-water reflections) which were remediated by excluding the offending data from further consideration; a second-stage quality assurance check was conducted by an independent and experienced observer. Finalized depth estimate grids were constructed as QPS Fledermaus digital terrain models (for visualization) and floating-point GeoTIFF images (for GIS applications and product construction). Maps were made using the Open Source QGIS software version 3.8.3-Zanzibar.

Oceanographic stations. Observations of temperature and salinity were made during the Ryder 2019 Expedition using a Seabird 911 CTD. The CTD was equipped with a 24 Niskin bottle (12 liters) rosette and the following sensors: Dual SeaBird temperature (SBE 3), conductivity (SBE 04C), dissolved oxygen (SBE 43), turbidity and fluorescence (WET Labs ECO-AFL/FL), and a Benthos Altimeter PSA-916D. In situ conductivity and temperature have been converted to potential temperature and absolute salinity (referred to as salinity in Fig. 4) using the TEOS10 equation of state, and are reported from stations inside Sherard Osborn Fjord, off the fjord mouth in the Lincoln Sea, and in Petermann Fjord.

Lowered ADCP. Two RDI Workhorse $(300 \mathrm{kHz})$ ADCPs were mounted on the CTD rosette (one upward- and one downward-looking). Data were processed with the LDEO IX13 LADCP package ${ }^{42}$, written in MATLAB and available from www. ldeo.columbia.edu/cgi-bin/ladcp-cgi-bin/hgwebdir.cgi.

Plume modelling. We used the one-dimensional buoyant-plume model developed and refined by Jenkins ${ }^{29,30}$. This model is based on conservation of mass, momentum, heat and salt ${ }^{43}$. The model setup and input parameters are further described in the Supplementary information where the results are presented.

\section{Data availability}

All data presented in the paper (multibeam bathymetry and oceanographic stations) are available in the Bolin Centre for Climate Research database. Multibeam bathymetry: https://doi.org/10.17043/ryder-2019-bathymetry. LADCP (current measurements): 
https://doi.org/10.17043/ryder-2019-ladcp. CTD stations: https://doi.org/10.17043/ryder2019-ctd.

Received: 6 May 2020; Accepted: 6 October 2020;

Published online: 04 November 2020

\section{References}

1. Reeh, N. In Arctic Ice Shelves and Ice Islands (eds Copland, L. \& Mueller, D.) 75-106 (Springer, Netherlands, 2017).

2. Gudmundsson, G. H. Ice-shelf buttressing and the stability of marine ice sheets. Cryosphere 7, 647-655 (2013).

3. Straneo, F. \& Heimbach, P. North Atlantic warming and the retreat of Greenland's outlet glaciers. Nature 504, 36-43 (2013).

4. Christoffersen, P. et al. Warming of waters in an East Greenland fjord prior to glacier retreat: mechanisms and connection to large-scale atmospheric conditions. Cryosphere 5, 701-714 (2011).

5. Benn, D. I., Warren, C. R. \& Mottram, R. H. Calving processes and the dynamics of calving glaciers. Earth-Sci. Rev. 82, 143-179 (2007).

6. Rückamp, M., Neckel, N., Berger, S., Humbert, A. \& Helm, V. Calving induced speedup of Petermann Glacier. J. Geophys. Res. 124, 216-228 (2019).

7. Mouginot, J. et al. Fast retreat of Zachariæ Isstrøm, northeast Greenland. Science 350, 1357-1361 (2015).

8. Mouginot, J. et al. Forty-six years of Greenland Ice Sheet mass balance from 1972 to 2018. Proc. Natl Acad. Sci.USA 116, 9239-9244 (2019).

9. van den Broeke, M. et al. Greenland Ice Sheet surface mass loss: recent developments in observation and modeling. Curr. Clim. Change Rep. $\mathbf{3}$ 345-356 (2017).

10. Aschwanden, A. et al. Contribution of the Greenland Ice Sheet to sea level over the next millennium. Sci. Adv. 5, eaav9396 (2019).

11. Bamber, J. L., Oppenheimer, M., Kopp, R. E., Aspinall, W. P. \& Cooke, R. M. Ice sheet contributions to future sea-level rise from structured expert judgment. Proc. Natl. Acad. Sci. USA 116, 11195 (2019).

12. Fenty, I. et al. Oceans melting Greenland: early results from NASA's OceanIce Mission in Greenland. Oceanography 29, 71-83 (2016).

13. Rignot, E., Fenty, I., Xu, Y., Cai, C. \& Kemp, C. Undercutting of marineterminating glaciers in West Greenland. Geophys. Res. Lett. 42, 5909-5917 (2015).

14. Schaffer, J. et al. Bathymetry constrains ocean heat supply to Greenland's largest glacier tongue. Nat. Geosci. 13, 227-231 (2020).

15. Hill, E. A., Carr, J. R., Stokes, C. R. \& Gudmundsson, G. H. Dynamic changes in outlet glaciers in northern Greenland from 1948 to 2015. Cryosphere 12, 3243-3263 (2018).

16. Mottram, R. et al. An integrated view of Greenland Ice Sheet mass changes based on models and satellite observations. Remote Sens. 11, 1407 (2019).

17. Jakobsson, M. et al. The Holocene retreat dynamics and stability of Petermann Glacier in northwest Greenland. Nat. Commun. 9, 2104 (2018).

18. Münchow, A., Padman, L. \& Fricker, H. A. Interannual changes of the floating ice shelf of Petermann Gletscher, North Greenland, from 2000 to 2012. J. Glaciol. 60, 489-499 (2014).

19. Johannessen, O. M., Babiker, M. \& Miles, M. W. Unprecedented retreat in a 50 -year observational record for Petermann Glacier, North Greenland. Atmos. Ocean. Sci. Lett. 6, 259-265 (2013).

20. Rudels, B. et al. Observations of water masses and circulation with focus on the Eurasian Basin of the Arctic Ocean from the 1990s to the late 2000s. Ocean Sci. 9, 147-169 (2013).

21. Münchow, A., Padman, L., Washam, P. \& Nicholls, K. W. The ice shelf of Petermann Gletscher, North Greenland, and its connection to the Arctic and Atlantic Oceans. Oceanography 29, 84-95 (2016).

22. Davies, W. E. \& Krinsley, D. B. in Symposium of Bergurgl, Austria, 119-130 (International Association of Scientific Hydrology, 1962).

23. Koch, L. Contributions to the glaciology of North Greenland. Medd. Grønl. 65, 181-464 (1928).

24. Dowdeswell, J. A. et al. The variety and distribution of submarine glacial landforms and implications for ice-sheet reconstruction. Geol. Soc. Lond. Mem. 46, 519-552 (2016).

25. Batchelor, C. L. \& Dowdeswell, J. A. Ice-sheet grounding-zone wedges (GZWs) on high-latitude continental margins. Mar. Geol. 363, 65-92 (2015).

26. Dowdeswell, J. A. \& Fugelli, E. M. G. The seismic architecture and geometry of grounding-zone wedges formed at the marine margins of past ice sheets. Geol. Soc. Am. Bull. 124, 1750-1761 (2012).

27. Rudels, B. et al. in Arctic Climate Change: The ACSYS Decade and Beyond, Vol. 43 (ed. Lemke, P.) Ch. 4, 117-198 (Springer, 2012).
28. Wilson, N., Straneo, F. \& Heimbach, P. Satellite-derived submarine melt rates and mass balance (2011-2015) for Greenland's largest remaining ice tongues. Cryosphere 11, 2773-2782 (2017)

29. Jenkins, A. Convection-driven melting near the grounding lines of ice shelves and tidewater glaciers. J. Phys. Oceanogr. 41, 2279-2294 (2011).

30. Jenkins, A. A one-dimensional model of ice shelf-ocean interaction. J. Geophys. Res. 96, 20671-20677 (1991).

31. Holland, D. M., Thomas, R. H., Young, B. D., Ribergaard, M. H. \& Lyberth, B. Acceleration of Jakobshavn Isbræ triggered by warm subsurface ocean waters. Nat. Geosci. 1, 659-664 (2008).

32. Amundson, J. M. et al. Glacier, fjord, and seismic response to recent large calving events, Jakobshavn Isbræ, Greenland. Geophys. Res. Lett. 35, L22501 (2008).

33. Morlighem, M. et al. BedMachine v3: complete bed topography and ocean bathymetry mapping of Greenland from multibeam echo sounding combined with mass conservation. Geophys. Res. Lett. 44, 11,051-011,061 (2017).

34. Tinto, K. J., Bell, R. E., Cochran, J. R. \& Münchow, A. Bathymetry in Petermann fjord from operation IceBridge aerogravity. Earth Planet. Sci. Lett. 422, 58-66 (2015).

35. Gade, H. G. Melting of ice in sea water: a primitive model with application to the Antarctic Ice Shelf and Icebergs. J. Phys. Oceanogr. 9, 189-198 (1979).

36. Washam, P., Nicholls, K. W., Münchow, A. \& Padman, L. Summer surface melt thins Petermann Gletscher Ice Shelf by enhancing channelized basal melt. J. Glaciol. 65, 662-674 (2019).

37. Turner, J. S. Turbulent entrainment: the development of the entrainment assumption, and its application to geophysical flows. J. Fluid Mech. 173 431-471 (1986).

38. Johnson, H. L., Münchow, A., Falkner, K. K. \& Melling, H. Ocean circulation and properties in Petermann Fjord, Greenland. J. Geophys. Res. 116, C01003 (2011).

39. Little, C. M., Gnanadesikan, A. \& Oppenheimer, M. How ice shelf morphology controls basal melting. J. Geophys. Res. 114, https://doi.org/ 10.1029/2008jc005197 (2009).

40. Holland, P. R. The transient response of ice shelf melting to ocean change. $J$. Phys. Oceanogr. 47, 2101-2114 (2017)

41. Calder, B. R. \& Mayer, L. A. Automatic processing of high-rate, highdensity multibeam echosounder data. Geochem. Geophys. Geosyst. 4, 1-22 (2003).

42. Visbeck, M. Deep velocity profiling using lowered acoustic Doppler current profilers: bottom track and inverse solutions. J. Atmos. Ocean. Technol. 19, 794-807 (2002).

43. Morton, B. R., Taylor, G. I. \& Turner, J. S. Turbulent gravitational convection from maintained and instantaneous sources. Proc. R. Soc. Lond. Ser. A 234, $1-23$ (1956).

44. Joughin, I. A. N., Smith, B. E., Howat, I. M., Moon, T. \& Scambos, T. A. A SAR record of early 21 st century change in Greenland. J. Glaciol. 62, 62-71 (2016).

\section{Acknowledgements}

We thank the Captain and crew of Icebreaker Oden, as well as the personnel from the Swedish Polar Research Secretariat, for stellar logistical support. We appreciated comments by Jan Backman on an early version of this manuscript and constructive comments by two anonymous reviewers. The Ryder 2019 Expedition was endorsed as Explorer's Club Flag Expedition \#51. We thank the Swedish Polar Research Secretariat, Center for Coastal and Ocean Mapping/University of New Hampshire and Stockholm University for supporting the Ryder 2019 Expedition financially. M.J., M.O., V.B. and colleagues from Stockholm University were supported by grants from the Swedish Research Council (VR; grants 2016-04021, 2016-05092, 2018-04979). T.M.C. and L.G. were funded by the U.S. Geological Survey Land Change Science Programme. Adrian Jenkins from British Antarctic Survey is thanked for providing the plume model and feedback on the results. J.C. was financially supported by the Ocean Frontier Institute through the Canada First Research Excellence fund.

\section{Author contributions}

M.J and L.A.M. conceived the original idea of the paper. J.N. and C.S. contributed equally to the writing and development of the oceanographic aspects. All other authors (B.C., M.O., J.W.F., T.M.C., V.B., J.C., B.E., J.F., L.G., A.G., F.A.H., K.J., N.K., A.M., J.M., A.P., B.R., B.T., A.U., E.W., H.Å., T.H., E.S., L.-G.B., S.R., G.W., J.P.) have provided input on the paper and participated in various ways in the data collection and processing.

\section{Funding}

Open Access funding provided by Stockholm University. 


\section{Competing interests}

The authors decare no competing interests.

\section{Additional information}

Supplementary information is available for this paper at https://doi.org/10.1038/s43247020-00043-0

Correspondence and requests for materials should be addressed to M.J.

Peer review information Primary handling editor: Joe Aslin.

Reprints and permission information is available at http://www.nature.com/reprints

Publisher's note Springer Nature remains neutral with regard to jurisdictional claims in published maps and institutional affiliations. (c) (i) Open Access This article is licensed under a Creative Commons Attribution 4.0 International License, which permits use, sharing, adaptation, distribution and reproduction in any medium or format, as long as you give appropriate credit to the original author(s) and the source, provide a link to the Creative Commons license, and indicate if changes were made. The images or other third party material in this article are included in the article's Creative Commons license, unless indicated otherwise in a credit line to the material. If material is not included in the article's Creative Commons license and your intended use is not permitted by statutory regulation or exceeds the permitted use, you will need to obtain permission directly from the copyright holder. To view a copy of this license, visit http://creativecommons.org/ licenses/by/4.0/.

(C) The Author(s) 2020 